\title{
Life Insurance in India: the Relationship between Reforms and Growth in Business
}

\author{
Amlan Ghosh \\ Department of Management and Commerce, School of Management and Commerce, Sikkim University, \\ $6^{\text {th }}$ Mile, Tadong, Gangtok, Sikkim 737102, India.
}

Reforms in the Indian life insurance sector began in 1999 and since then the growth of the life business has been impressive despite some restrictions. Whether the reforms in this sector have helped the industry to grow or not is an empirical matter. We, therefore, studied the relationship between life insurance sector reforms in India and the growth of life business in the post-reform period. At the empirical level, we first construct an index to measure the reforms and then used the VAR-VECM model to find out the long-run relationship. The Granger causality test suggests that life insurance sector reforms improved the overall development of life insurance development in recent years in India.

The Geneva Papers (2013) 38, 88-112. doi:10.1057/gpp.2012.2

Keywords: life insurance reforms; VAR; VECM; Indian life insurance; Granger causality; India

Article submitted 28 May 2009; accepted 5 December 2011; published online 13 June 2012

\section{Introduction}

Liberalisation of the domestic financial market has been a common characteristic of a number of economies since the late 1960s. This was particularly true in the case of industrially advanced countries such as Australia, Japan, U.K. and France. ${ }^{1}$ However, this has not been confined to these industrially developed countries only. In recent years, many Least Developed Countries (LDCs) have undertaken macroeconomic reforms, which involve structural adjustment programmes. The main concentration was towards the financial system, especially banking and insurance sectors, which was typically either owned or controlled by the state itself. Developing countries such as India, along with other semi-industrialised countries, have opened up their financial sectors. ${ }^{2}$

The New Economic Policy introduced in India in June 1991 by the then newly elected government and the process of liberalisation of the Indian financial sector, are part of that new policy. The main thrust of reforms in the financial sector was the creation of efficient and stable financial institutions and markets. Reforms in the banking and non-banking sectors focused on creating a deregulated environment, strengthening the prudential norms and the supervisory system, changing the

\footnotetext{
${ }^{1}$ Rao (2000).

${ }^{2}$ UNCTAD (1993).
} 
ownership pattern, and increasing competition. The main ideas are globalisation, privatisation, deregulation and liberalisation.

With the paradigm shift in the development strategy, the economy is increasingly opening up and there is a step forward towards market orientation. Consequently, some financial markets such as capital market, forex market and the banking sector have reformed to various degrees. The insurance sector has yet to undergo reform initiatives to benefit from recent global changes. The Uruguay Round of GATT (now WTO) also advocated the removal of restrictions and non-tariff trade barriers to free flow of international services across countries so that domestic markets of LDCs can improve their efficiency and competitiveness and eventually improve their economic growth. ${ }^{3}$ It is against this backdrop that many countries have deregulated their insurance sector and countries that already allowed private insurance business further deregulated their reinsurance business, such as Pakistan (1990), Argentina (1990), Brazil (1991), Peru (1991) and Czechoslovakia (1992).

In India, reforms in the insurance sector (life and general) commenced with the setting up of the Committee on Reforms on Insurance Sector under the chairmanship of Dr. R.N. Malhotra, the ex-governor of Reserve Bank of India (RBI), by the Government of India in April 1993, in order to examine the structure of the insurance industry. The recommendations of the Committee were submitted in 1994, and were accepted in principle by the government that started implementing the recommendations in December 1999, thus heralding an era of liberalisation in the country's insurance sector. The setting-up of the Insurance Regulatory and Development Authority (IRDA) and the opening up of insurance business (life and general) to foreign capital up to 26 per cent, were the initial steps in this direction. It is widely acknowledged that the opening up of the insurance sector was aimed at ushering in greater efficiency in the insurance business by maximising productivity and minimising transaction cost. Competition is believed to bring a wider choice of products at lower prices to the consumers, larger coverage of population, better customer service, superior information technology, higher returns to policyholders and so on. In this study, we will focus on life insurance activities in India, as this segment contributes more than 90 per cent of the total business of the insurance industry.

At present, there are 22 private life insurers operating in the Indian life insurance market along with the only state-owned life insurer, Life Insurance Corporation of India (LICI), at the end of the financial year 2009/2010. According to the IRDA, total premium income of all the life insurers increased by 18 per cent during 2009/2010 to US\$56.04 billion against US\$47.6 billion in the previous year, and the total first-year premium collected in 2009/2010 was US\$24.64 billion, an increase of 25.46 per cent over US\$19.64 billion collected in 2008/2009; the life insurance industry is expected to cross the US\$66.8 billion total premium income mark in 2010/2011. During 2009, the life insurance premium (LIP) in India grew by 10.1 per cent (inflation adjusted) conversely, and during the same period the global LIP

\footnotetext{
3 Tadas (1994).
} 
a
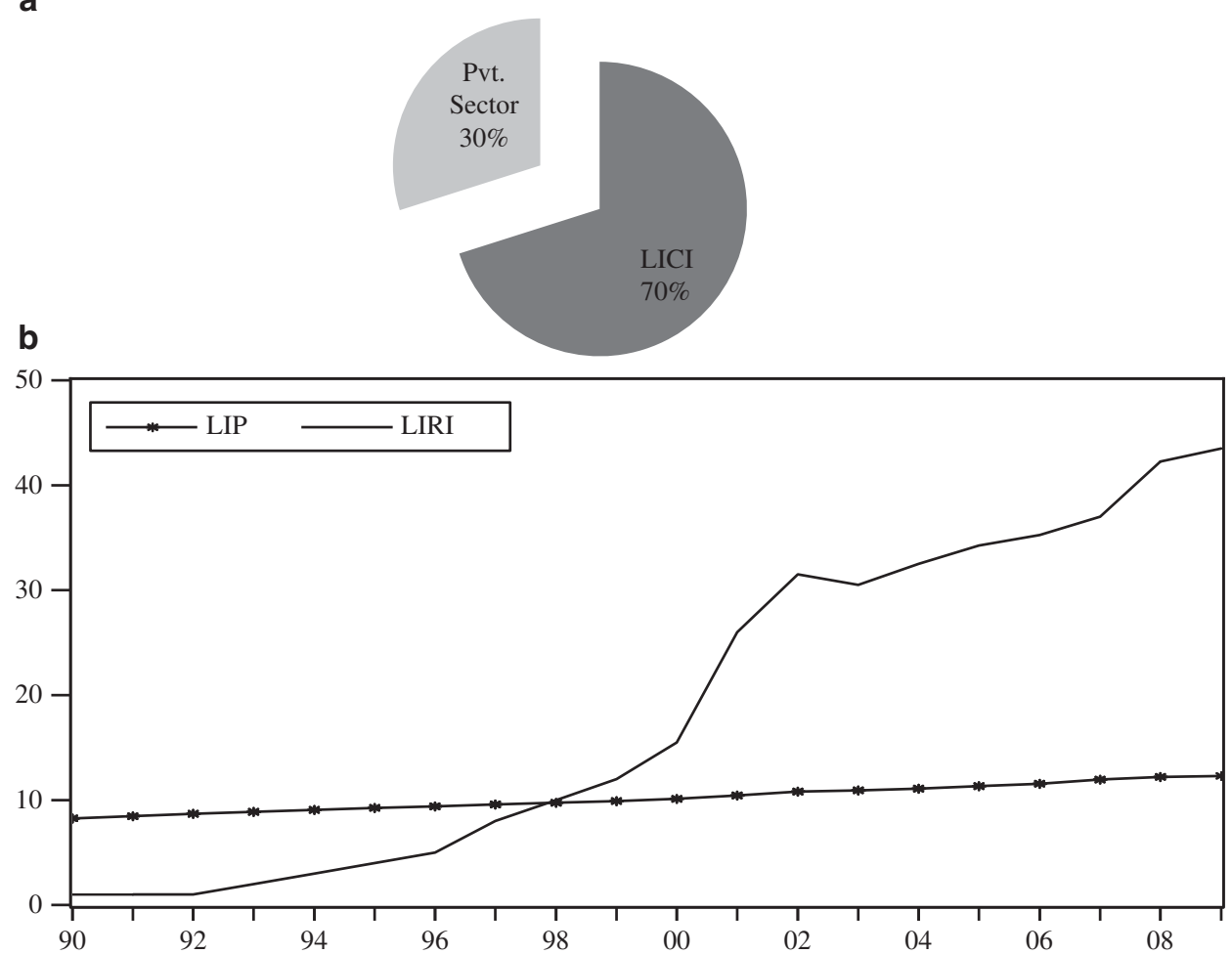

Figure 1. (a) Indian life insurance market share (2009/2010). (b) Graphical presentation of life premium and life insurance reforms index at levels.

Source: Annual Report, $2010^{4}$, IRDA.

contracted by 2 per cent. The share of the Indian life insurance sector in the global market was 2.45 per cent in 2009, as against 1.98 per cent in 2008 .

In India, private life insurers are slowly gaining momentum to penetrate the market with their new products, services and global knowledge of expertise in doing life business. This can be witnessed from their growing market share statistics, which shows (Figure 1) that almost 30 per cent of the market is in their hands at the end of 2009/2010 financial years. The most important aspect is that their acceptability is on the rise though it is an urban phenomenon. The prominent private players operating actively are ICICI Prudential Life, Bajaj Allianz Life, SBI Life, HDFC Standard Life, Birla Sun Life, Reliance Life, Max New York Life and TATA AIG Life Insurance Company.

The Indian life insurance market witnessed the most important development in the rural market, which is a huge market for insurers, as nearly more than 70 per cent of the population live in rural areas. Penetration in rural areas was made through the

\footnotetext{
${ }^{4}$ Annual Report (2009-2010).
} 
introduction of new customised products especially designed for the rural market and the introduction of micro-insurance products. The IRDA (insurance regulator) stipulates the minimum obligatory requirement for the entire insurer to serve rural areas under the IRDA Regulations, 2002, which is known as the "Obligations of Insurers to Rural or Social Sectors". Growth rate in the rural and social sector has definitely been picking up as a result of the IRDA's focus on this sector. India's life insurance firms have exceeded expectations in terms of growing their business in rural India, and most firms in the business are actually ahead of targets laid down by the IRDA.

The growth of micro-insurance (life) is decent, although the volume is still too small. A major percentage of micro-insurance business in $2009 / 2010$ was procured under group business, which amounted to INR 243.45 crore under 1.69 crore lives, while individual business accounted for INR 158.22 crore under 29.84 lakh life policies. The bulk of the micro-insurance business is contributed by the state-run life insurer LICI, which has managed to acquire INR 149.83 crore from 19.85 lakh individual lives and INR 228.69 crore group premium from 1.49 crore lives.

The number of micro-insurance agents has increased from 7,250 in 2008/2009 financial years to 8,676 in 2009/2010 financial years (Table 1). Once again, the staterun insurance company LICI has beaten the private life insurance companies convincingly in providing micro-insurance to the poor section of society. The performance of private life insurance companies is under the scanner, as they need to comply with the Rural and Social Sectors' Obligation under the new guidelines issued by the IRDA every year. This quota of the number of lives to be covered in one financial year creates pressure on life insurers operating in the market. If the insurers fail to comply with the prescribed number of lives under the Rural and Social Sectors' Obligation, there are instances in which the IRDA has fined some insurers. Fourteen life insurers have so far launched 28 micro-insurance products, and out of the 28 products, 15 are for individuals and the remaining 13 are for groups.

India recorded a phenomenal growth in the life insurance market development in the post-reform period both at the level of life insurance penetration (life premium as a per cent of GDP) and density (per capita life insurance expenditure) [two globally accepted measures of insurance development], which shows that the post-reform life insurance development is much higher than that of the pre-insurance reform era in India. During the pre-reform period, the level of penetration reached only 1.39 per cent in 1999. But the same has improved to 4.60 per cent in 2009. In the case of density, the level of per capita expenditure improved from US\$6.2 in 1999 to US\$47.7 in 2009. This paper tries to shed light on reforms in the life insurance market

Table 1 Micro-insurance agents: Life insurers

\begin{tabular}{lcr}
\hline Insurers & $\begin{array}{c}\text { Agents } \\
(01-04-2009)\end{array}$ & $\begin{array}{c}\text { Agents } \\
(31-03-2010)\end{array}$ \\
\hline Pvt. Life Insurance Companies & 603 & 770 \\
LICI & 6,647 & 7,906 \\
Industry total & 7,250 & 8,676 \\
\hline
\end{tabular}

Source: IRDA annual report, 2008-2009, and 2009-2010. 
and its impact on the life insurance market development in India. To do so, the first section of this paper examines the relevant literature in this sector. The second section focuses on the reforms initiated and implemented in the life insurance sector and tries to quantify the reforms so that we can empirically review the impact of these reforms in the total development of the life insurance sector in India. In the last section, the findings of the study will be provided.

\section{Literature review}

The role of financial development and economic growth has been well established by researchers and economic analysts in their empirical studies. ${ }^{5}$ These studies established the role of financial institutions and financial intermediaries in fostering economic growth by improving the efficiency of capital accumulation, encouraging savings and ultimately improving the productivity of the economy. Now, the research has shifted from the established link between financial development and economic growth to understanding factors that affect the overall financial services, and thus the underlying factors that lead to improving financial development.

Insurance is one of the important financial services that can trigger growth in an economy by channelling long-term savings for productive purposes and providing a shield against the risk associated with any activity related to productivity, assets or life. Recent studies show that the insurance industry can improve economic growth through financial intermediation, risk aversion and generating employment. For example, we can highlight the studies of Outreville, ${ }^{6}$ Catalan et al., ${ }^{7}$ and Ward and Zurbruegg. ${ }^{8}$

By identifying the macroeconomic factors that promote the demand for life insurance, it would be possible to find out the factors that actually work as a catalyst in promoting financial development and thereby economic growth. For example, recent empirical work on insurance markets by Browne and Kim, ${ }^{9}$ Outreville, ${ }^{10}$ Browne et al., ${ }^{11}$ Ward and Zurbruegg, ${ }^{7}$ Beck and Webb, ${ }^{12}$ Esho et al., ${ }^{13}$ Hwang and Gao, ${ }^{14}$ Hwang and Greenford, ${ }^{15}$ Lim and Haberman, ${ }^{16}$ and Zhang and $\mathrm{Zhu}{ }^{17}$ have shown that the level of insurance demand can be influenced by economic, demographic and legal factors. Despite the findings of several influencing factors affecting life

\footnotetext{
${ }^{5}$ King and Levine (1993a, b); Levine (1997); Levine and Zervos (1998); Beck et al. (2000); and Levine et al. (2000).

${ }^{6}$ Outreville (1990).

${ }^{7}$ Catalan et al. (2000).

${ }^{8}$ Ward and Zurbruegg (2002).

${ }^{9}$ Browne and Kim (1993).

${ }^{10}$ Outreville (1996).

11 Browne et al. (2000).

12 Beck and Webb (2002).

13 Esho et al. (2004).

${ }^{14}$ Hwang and Gao (2003).

15 Hwang and Greenford (2005).

${ }^{16}$ Lim and Haberman (2004).

${ }^{17}$ Zhang and Zhu (2005).
} 
insurance demand and the promotion of life insurance development, there is meek guidance for the policymakers to focus on specific factor/s to foster the life insurance development. More importantly, the focus on the demand side has neglected the supply side of the life insurance market. The causal relationship between insurance development and economic development has been well studied by Arena, ${ }^{18}$ who found that insurance activity does promote economic development. The study of Han et al. ${ }^{19}$ found that insurance development (life and general) plays a much more important role in economic development in a developing economy than in a developed economy.

There are few important studies on the Indian life insurance industry that need to be highlighted, as these are pioneer works in this sector. The work of Ranade and Ahuja ${ }^{20}$ justified the reforms in the insurance sector and evaluated the performance of the state-run life insurer LICI. Rao ${ }^{1}$ has examined the implications of reforms in the life insurance industry and advocated a cautious approach along with institutional and legal reforms.

There are some other notable studies that have tried to examine the trends and growth of the insurance sector in India in the post-insurance reform period, such as the works of Sinha, ${ }^{21}$ who theoretically explains the state of development in India's insurance market and enumerates the opportunities and challenges offered by the insurance market in the years to come.

Rajagopalan, ${ }^{22}$ in his study, tried to examine the impact of liberalisation of the insurance market in valuing term insurance products in the Indian market to determine whether or not competition has brought down the cost of premiums.

Tone and $\mathrm{Sahoo}^{23}$ examined the cost efficiency of LICI in the post-reform era and the study of Sinha and Chatterjee ${ }^{24}$ estimated cost efficiency of all the life insurers operating in India in the post-reform period and found improved cost efficiency.

The study of Mitra and Ghosh ${ }^{25}$ studied the post-reform situation of the Indian rural life insurance market and the role played by all the insurers in this market. The study also highlighted the emerging role of the Post Office Savings Bank in spreading life insurance cover to the rural areas.

The very recent study of Mitra and Ghosh ${ }^{26}$ finds that Gross Disposable Personal Income (GDPI) and Financial Development (FD) are the most significant and positive factors in driving life insurance demand in India. Further, the study of Vadlamannati ${ }^{27}$ shows that insurance reforms have a positive effect on economic development in India. But the objective of this study is to evaluate the life insurance reforms, which are one of the factors leading to the increase in the number of players in the market along

\footnotetext{
${ }^{18}$ Arena (2008).

${ }^{19}$ Han et al. (2010).

${ }^{20}$ Ranade and Ahuja (1999).

${ }^{21}$ Sinha (2004).

22 Rajagopalan (2004).

23 Tone and Sahoo (2005).

${ }^{24}$ Sinha and Chatterjee (2009).

${ }^{25}$ Mitra and Ghosh (2009).

${ }^{26}$ Mitra and Ghosh (2010).

${ }^{27}$ Vadlamannati (2008).
} 
with the array of product choices for consumers in India, and to investigate the effects of these reforms empirically on the total development of life insurance business in India and not the economic development. No such study has yet been published so far on the Indian life insurance market after the implementation of reforms in this sector in 1999, and to the best of the author's knowledge this is the first such attempt at measuring the effects of life insurance reforms empirically. The prime objective of this paper is to find out the causal relationship between life insurance reforms and overall life insurance development in India, and by doing so we would be able to answer whether or not we need more reforms in this sector. This study is also significant as the new Insurance Bill, which will allow more reforms (e.g. increasing the Foreign Direct Investment (FDI) cap of foreign insurers from the present level of 26 per cent to 49 per cent) in the insurance sector, is pending with the Indian parliament.

\section{Measuring life insurance reforms}

In this section, we will try to evaluate empirically the effect of life insurance reforms on the overall development of the life insurance business in India. Therefore, the study has identified the dependent variables and explanatory variable along with a few control variables that affect the overall life insurance development in India. As far as the published literature is concerned, no such attempt has been made so far, at least at the time of writing this section, by any researcher to investigate empirically the effects of reforms in the life insurance sector and its implications for the market in India. To do so, the first problem is how to measure reforms in the life insurance sector. There is no such accepted measure available to be used in our study. Therefore, this study is considered to construct a composite index of life insurance reforms, which can be used in our study to find out the existing relationship between reforms and the development of the life market in India. To construct the index that has been named as Life Insurance Reforms Index (LIRI), I have considered the fundamentals that are post-reform phenomena, that is, those elements that manifest the reforms initiatives in this sector. We have considered major policy reforms and regulatory reforms in constructing the LIRI. The following are the main categories that have been measured to construct the LIRI:

(a) FDI in life insurance business, and

(b) Regulatory reforms in life insurance sector.

\section{FDI in life insurance business}

In the post-reform period, India witnessed joint ventures in the life insurance industry with foreign companies, bringing a maximum of 26 per cent capital, which is stipulated by the regulator IRDA. Since there is a cap on the FDI in India, foreign companies cannot operate individually in the insurance market in India. Due to this regulation, foreign companies need to collaborate with a domestic company to enter into the life market. This FDI cap reduces the operational ability of foreign companies in India, 
and therefore we believe that the volume of FDI every year would not show the exact picture of the life insurance industry in India as it would be always 26 per cent of the total capital along with the foreign assets in new life insurance companies. Using the market share of new private foreign life insurance companies is also not convincing as a measure of FDI in the life insurance sector in India as these companies are very new and whatever market share they have achieved is mostly concentrated in the urban areas, which represents only the urban market of India and not the huge untapped rural market. Thus, we need to come up with a simple measure that defines FDI in the life insurance sector. Let us presume the number of new entrants of foreign and domestic companies every year to proxy FDI in the life insurance sector. FDI scores in the life insurance sector would be calculated as

FDI in life insurance sector $=1$ for every one new entrant in this sector.

$=2$ for every two new entrants in this sector, and so on.

That is, if in any given year there are six new foreign entries, then score would be 6 in that particular year.

\section{Regulatory reforms in the life insurance sector}

It is a very demanding and complicated task to quantify the regulatory reforms process in the life insurance sector, and it is more difficult when these reforms are in the nascent stage. Therefore, there is a need for an effective scoring system that will, eventually, define the regulatory reforms initiated and taken by the government. To measure the regulatory reforms, the following scoring system is applied in this study:

Life insurance Regulatory reforms $=0$ for no reforms initiatives and steps;

$=1$ for setting-up of any committee;

$=1$ for report submitted by any committee;

$=1$ for any report accepted by the government;

$=1$ for passing any bill in the parliament; and

$=0.25$ for every new regulation framed under the IRDA Act, 1999, to date.

As far as regulations are concerned, forming a committee and subsequently submitting the report of that committee in parliament and eventually the passing of that Bill is quite a long and democratic process, which is very important in implementing laws and reforms in any sector in India. The insurance sector reforms process has also witnessed the same, as we know that it took almost eight long years to pass the insurance reforms bill in the year 2000 in Parliament after the formation of the Malhotra Committee in 1993 and subsequent submission of the report in 1994. Therefore, we have given importance to the committee formations and reports and passing of those reforms bill in Parliament. Vadlamannati ${ }^{28}$ also used similar kinds of parameters in his study. In calculating the life insurance regulatory reforms, we have 
started from 1993 when the first step towards opening of the insurance sector was taken by the formation of the Malhotra Committee. Thus, we have given a score of 1 in that year until any other major steps are taken. In 1994, the committee submitted its report, which adds another 1 point to the total score. Again, in 1995, another committee, the Mukherjee Committee, was formed in the insurance sector. This also adds one more to the score of the life insurance regulatory reforms. This is how we have continued and come up with a score to quantify LIRI. For the total development of the life insurance industry, see the chronology of reforms in the life insurance sector and regulations framed under the IRDA Act 1999, in the Appendix.

Total LIP volume will be used to measure the development of life insurance business in India. We have used a few macroeconomic indicators as control variable in our Ordinary Least Square (OLS) equation to study the impact of life insurance reforms. These are

Gross Disposable Personal Income (GDPI): An individual's consumption increases with the increase in his/her income, which makes life insurance more affordable. As income increases, the need for life insurance also increases to protect the principal wage earner for the income flow in future and also to protect the dependants against the loss of premature death and to meet the expected consumption of his/her dependants. Previous studies of life insurance consumption have used gross national product (GNP) and gross domestic product (GDP) to proxy income. However, both GDP and GNP less accurately reflect the amount of disposable personal income. Therefore, we are inclined to use per capita real personal disposable income (GDPI) as a measure of income. This variable also takes into account population growth in the economy along with an improved economy.

Inflation (wholesale price index): Inflation has a significant negative impact on demand for life insurance products. A rising inflation rate leads to a devaluation of future benefits from purchasing life insurance. In a country that is experiencing a high inflation rate, life insurance may not be able to serve the interest of individuals and families as a savings product or as a product that will benefit in future eventualities. Inflation erodes the value of life insurance.

In India, inflation plays a vital role in the day-to-day life of every citizen as it affects the household directly. Generally, inflation pressure on food prices is more vulnerable than any other segment of the economy, as India has 300 million middle-class people in addition to 26 per cent of the population that lives below the poverty line. As inflation hits the household directly in India, inflationary pressure tends to reduce the savings behaviour of common people. This may have an effect on the demand for life insurance products and in turn the development of the life business in India. Rate of change in the yearly wholesale price index (WPI) ${ }^{28}$ is used here as a measure of inflation, as it reflects the real effects on households all over India.

\footnotetext{
${ }^{28}$ The variation in the price level in India can be measured in terms of the WPI, or the Implicit National Income Deflator (NID) or the Consumer Price Index (CPI). The WPI is the main measure of the rate of inflation often used in India justifiable on grounds of convenience as well as analytical reasoning. First, the commodity coverage in WPI is wider than that in CPI, and second, WPI is computed on an all-India basis whereas CPI is just constructed for specific centres and then aggregated to get the all-India index. Because of this feature, the majority of the public more easily understands WPI.
} 
Gross Domestic Savings (GDS): Rate of savings is an important constituent in driving the life insurance growth in a country. The rate of savings in the financial sector improves the fund allocation into the insurance sector, which in turn promotes economic development, as the insurance sector channels large amounts of funds for longer periods of time. We have used the gross national savings rate to assess the impact of savings rates on life insurance development.

\section{Data and methodology}

The present study will extensively use various statistical methods to address the problem under consideration. We intend to employ time-series analysis for the purpose of assessing the gain in efficiency in India's insurance sector after liberalisation. Since the economic liberalisation took place in India in 1991 and insurance reforms started only in 1992, time-series analysis may involve the problems of small sample. We will, therefore, alternatively use OLS to measure the gain in efficiency.

All the data series are annual aggregate data for the period starting from 1990/1991 to $2008 / 2009$ and secondary in nature. All the annual data is collected from annual reports of LICI and IRDA, Handbook of Statistics on Indian Economy, RBI, International Financial Statistics (IFS) database from IMF and various issues and reports from Swiss Re. LIP volume data is collected from sigma issues, annual reports of LICI and annual reports of IRDA. In constructing the LIRI, we have used various sources such as reports from Ministry of Finance, Govt. of India, Regulations framed by the IRDA from annual reports of IRDA. All the economic variables used as control variables are collected from the RBI.

First, we estimate the impact of life insurance reforms on the development of the life insurance sector along with the other control variables. However, before going on to time-series regression analysis, it is imperative to investigate the univariate properties of all the variables under consideration. Formally, Augmented DickeyFuller $(\mathrm{ADF})^{29}$ and/or Phillips-Perron (PP) ${ }^{30}$ unit root test is going to be used to check the stationary properties of the variables, whether the variables are stationary or non-stationary because using non-stationary time-series variable in the regression may give spurious results. Non-stationary variables may be used in our model provided the series are co-integrated in the same order. Therefore, the EngleGranger $^{31}$ co-integration test will be employed to verify co-integration among the variables.

In the next step, we estimate the long-run relationship between the two key variables, LIRI and LIP, and their causal relationship. We also check the short-run dynamics of our model by using the VAR-VECM technique.

\footnotetext{
${ }^{29}$ Dickey-Fuller (1979).

${ }^{30}$ Philips-Perron (1987).

${ }^{31}$ Engle and Granger (1987).
} 


\section{Econometric model to estimate the effects of reforms on life insurance development}

We have estimated the following model to evaluate the impact of reforms in the insurance sector on the overall development of this sector in India:

$$
L I P_{t}=\alpha+\beta_{1} L I R I_{t}+\sum_{i=1}^{n} \beta_{i} C_{i}+\varepsilon_{t}
$$

where, $L I P_{t}=$ Life Insurance Premium in $t$ year, $L I R I_{t}=$ Life Insurance Reform Index in $t$ year, $C_{t}=$ set of key control variables, $\varepsilon_{t}=$ Pure white noise error term and $\alpha, \beta=$ constant parameters.

\section{Empirical findings}

The first step is to transform the total LIP and income (GDPI) by taking the natural logarithm of their level values; however, variables of rate values are not transformed because they are already in a preferred form as they are a measure of change. Accordingly, the variables of rate value form, that is, life insurance reform index (LIRI), inflation (WPI) and GDS rate, are not transformed as they are in the required form. In the second step, the ADF unit root test is conducted to investigate stationary properties of the variables. Using non-stationary time-series variables in the regression might give spurious results. Non-stationary variables may be used in our model provided the series are co-integrated. Therefore, after conducting ADF unit root test, if the variables are found to be non-stationary, a co-integration study using ADF is also done to corroborate that the variables are co-integrated before running the regression.

The results of the ADF unit root test indicate that the variables (dependent and independent) have unit root at their level values at 10 per cent, 5 per cent and 1 per cent significance levels. That is, the series are non-stationary and integrated of order $(I)$. The results of the ADF unit root tests are summarised in the Table A3 (Appendix).

From Table A3, it is observed that the computed ADF test statistics for all the data series (except in case of WPI where the Durbin-Watson (DW) statistic is low but we have confirmed the results with the help of correlogram) are greater than the critical values (i.e. ADF test statistics lie to the right of the critical values). Since the computed ADF test statistics are greater than the critical values (at different level of significance), we cannot conclude to reject null hypothesis, that is, $\mathrm{H}_{0}$. That means all the series have a unit root problem and the series is a non-stationary series.

Since the series under study is non-stationary in nature, we cannot run a regression unless the variables of the series are co-integrated. Therefore, a co-integration test is conducted using ADF test. The basic purpose of the co-integration test is to determine whether or not a group of non-stationary variables are co-integrated. Engle and Granger $^{31}$ point out that the two non-stationary variables can be used in regression if the linear combination of the two non-stationary variables is stationary. An equilibrium theory that involves non-stationary variables requires that the combination of the variables be stationary. Therefore, we can rewrite the Eq. (1) as

$$
\varepsilon_{t}=L I P_{t}-\alpha+\beta_{1} L I R I_{t}+\sum_{i=1}^{n} \beta_{i} C_{i}
$$


Table 2 Unit root test

(a) ADF unit root test for lag length: 0 (automatic based on modified AIC, maximum lag =4)

\begin{tabular}{llllllll}
\hline Variables & Null hypothesis & ADF test stat. & Prob & DW stat & & \multicolumn{2}{c}{ Critical values } \\
\cline { 5 - 8 } & & & & $1 \%$ & $5 \%$ & $10 \%$ \\
\hline$\left(\varepsilon_{t}\right)$ & $\left(\varepsilon_{t}\right)$ has a unit root (none) & -4.9497 & 0.0001 & 1.967 & -2.6997 & -1.9614 & -1.6096 \\
\hline
\end{tabular}

(b) Philips-Perron unit root test for bandwidth: 2 (Newey-West using Bartlett Kernel)

\begin{tabular}{llcccccc}
\hline Variables & Null hypothesis & PP test stat. & Prob $^{\mathrm{a}}$ & \multirow{2}{*}{ DW stat } & & \multicolumn{2}{c}{ Critical values $^{2}$} \\
\cline { 4 - 8 } & & & & $1 \%$ & $5 \%$ & $10 \%$ \\
\hline$\left(\varepsilon_{t}\right)$ & $\left(\varepsilon_{t}\right)$ has a unit root (none) & -3.6593 & 0.0010 & 1.967 & -2.6923 & -1.9601 & -1.6070 \\
\hline
\end{tabular}

${ }^{a}$ MacKinnon (2000) one-sided $P$-value.

Since $\varepsilon_{t}$ must be stationary, this means that the linear combination of the nonstationary (integrated) variables given in the right-hand side must also be stationary. Stationarity of the error term $\left(\varepsilon_{t}\right)$ has been checked by both the ADF unit root test and PP unit root test and the results of the test are summarised in Table 2(a) and (b).

From the tables, it is observed that the computed ADF/PP unit root test statistics for all the data series are smaller than the critical values (i.e. ADF/PP test statistics lie to the left of the critical values). Since the computed ADF/PP test statistics is smaller than the critical values (at 1 per cent level of significance), we can conclude to reject null hypothesis that is, $\mathrm{H}_{0}$. It means that the residual series $\left(\varepsilon_{t}\right)$ does not have a unit root problem and the $\left(\varepsilon_{t}\right)$ series is a stationary series at the 1 per cent significant level. The DW statistic is 1.96 , which means the $\left(\varepsilon_{t}\right)$ series does not have any autocorrelation problem. Now, we can use these non-stationary variables in Eq. (1) as they are cointegrated. The results of the initial OLS estimation of Eq. (1) are furnished in Table 3.

The above estimation of Eq. (1) shows that the LIRI, Income (GDPI) and inflation (WPI) are the significant variables associated with the development of life insurance business in India. Income (GDPI), reforms (LIRI) and inflation (WPI) are positively related with the development for life insurance in India. A close observation also shows that the inflation variable is not consistent in spite of being significantly related with the LIP.

From the results of Table 3, it is clear that the above-mentioned variables (GDPI, WPI, LIRI and GDS) collectively explain about 99 per cent of the variance in the demand for life insurance in India being adjusted $R^{2}=0.987$ and $P$-value $=0.0000$. Only 2 per cent of the variance is not explained by the regression model we have used in this study. The test for normality (JB Statistic $=0.60717, P$-value $=0.73816$ ) indicates that the residuals are normally distributed.

\section{Estimating long-run relationship}

We have used two variables in our study to analyse the reforms initiative in India. We used the total LIP volume as a measure of development of life insurance business in 
Table 3 The results of the initial Ordinary Least Square (OLS) estimation of Eq. (1)

Dependent variable: Life Insurance Premium (LIP)

Method: Least Squares

Sample (adjusted): 20 (1990-2009)

\begin{tabular}{lcccc}
\hline Variables & Coefficient & Std. Error & t-statistic & Prob. \\
\hline LIRI & 0.02984 & 0.00313 & 9.5099 & 0.0000 \\
GDPI & 1.04610 & 0.39967 & 2.6174 & 0.0194 \\
WPI & 1.21026 & 0.16751 & 7.2247 & 0.000 \\
GDS & 0.01256 & 0.01052 & 1.1495 & $\mathbf{0 . 2 6 8 3}$ \\
C & -6.44662 & 3.06254 & -2.1049 & 0.0526 \\
\hline$R$-squared & 0.9981 & Akaike info criterion (AIC) & -2.5425 \\
Adjusted $R^{2}$ & $\mathbf{0 . 9 8 7 6}$ & Schwarz criterion & -2.2936 \\
S.E. of regression & 0.0610 & F-statistic & 205.871 \\
Durbin-Watson stat. & $\mathbf{1 . 8 7 5 2}$ & Prob (F-statistic) & 0.000000 \\
\hline
\end{tabular}

India and a composite index (LIRI) to measure the life insurance reforms in India. To eliminate the heteroscedasticity, we have used the natural logarithm of LIP in our study. Let us denote specified variables as

$$
L_{t}=\log L I P \text { and } R_{t}=L I R I \text {. }
$$

In this study, we first check the stationary properties of the variables by using $\mathrm{ADF}$ test and PP test, as the non-stationary time-series variable might give spurious results. Non-stationary variables may be used in our model provided the series are co-integrated. Therefore, a co-integration study has also been done to verify this property. We will use the Engle-Granger ${ }^{31}$ co-integration test. We also check the short-run dynamics of our model by using the VAR-VECM technique.

\section{Stationarity tests}

Standard regression with non-stationary data leads to spurious relationship with erroneous conclusion. It therefore becomes pertinent to study the nature of the timeseries data involved in our study. In our study, one macroeconomic data series (total LIPs) is used, which generally follows the random walk. The stationarity of both series has been checked by the unit root test, which involves ADF tests and PP tests.

The results of the unit root tests are very sensitive to assumptions about the time series under test, for example trend, intercept, or both trend and intercept. To understand the importance of the nature of the series under the unit root test, we plot them graphically at their level values and after differencing.

From Figure 1, we can see that both the time series have some trend and intercept at their levels. Considering the particular nature of trend in both the series, we have differenced the data series once and the trends have been removed but the intercept remained, which can be seen in Figure 2. On the basis of these characteristics, the ADF test and PP test are performed. The results of both tests are summarised in the Tables A4 and A5 (Appendix). 


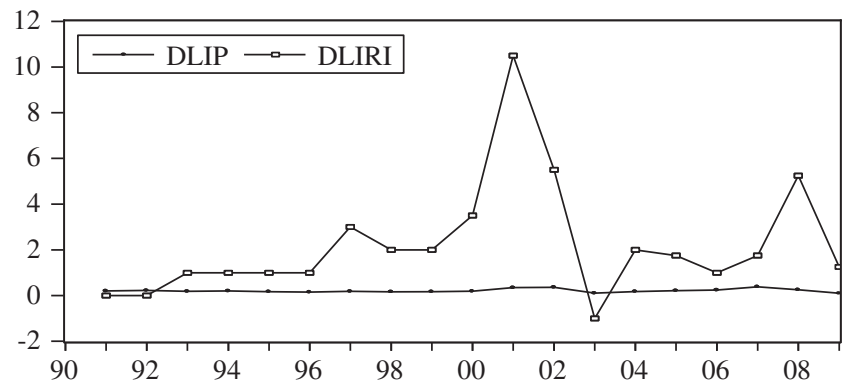

Figure 2. Graphical presentation of life premium and life insurance reforms index at first difference.

\begin{tabular}{|c|c|c|c|c|c|c|}
\hline Autocorrelation & Partial Correlation & & $\mathrm{AC}$ & PAC & Q-Stat & Prob \\
\hline$|* * * * * * *|$ & $|* * * * * * *|$ & 1 & 0.851 & 0.851 & 16.776 & 0.000 \\
\hline$|* * * * *|$ & $* 1.1$ & 2 & 0.694 & -0.112 & 28.535 & 0.000 \\
\hline$|* * * *|$ & $* \mid .1$ & 3 & 0.543 & -0.066 & 36.172 & 0.000 \\
\hline$|* * * \quad|$ & .1 .1 & 4 & 0.409 & -0.041 & 40.762 & 0.000 \\
\hline $.1 * * . \quad 1$ & $* 1.1$ & 5 & 0.283 & -0.067 & 43.106 & 0.000 \\
\hline$I^{*} . \mid$ & $* 1.1$ & 6 & 0.161 & -0.082 & 43.925 & 0.000 \\
\hline .1 .1 & $* 1.1$ & 7 & 0.042 & -0.099 & 43.984 & 0.000 \\
\hline$* 1.1$ & $* 1.1$ & 8 & -0.078 & -0.113 & 44.206 & 0.000 \\
\hline$* 1.1$ & .1 .1 & 9 & -0.178 & -0.056 & 45.477 & 0.000 \\
\hline$* * * 1.1$ & .1 .1 & 10 & -0.258 & -0.055 & 48.409 & 0.000 \\
\hline$* * * 1.1$ & $* 1.1$ & 11 & -0.326 & -0.082 & 53.609 & 0.000 \\
\hline$* * * 1$. I & 1. 1 & 12 & -0.371 & -0.037 & 61.198 & 0.000 \\
\hline$* * * 1.1$ & .1 .1 & 13 & -0.392 & -0.019 & 70.846 & 0.000 \\
\hline$* * * 1.1$ & $* 1.1$ & 14 & -0.402 & -0.061 & 82.674 & 0.000 \\
\hline$* * * \mid$ & 1. 1 & 15 & -0.397 & -0.039 & 96.578 & 0.000 \\
\hline$* * * \mid$. I & 1. I & 16 & -0.375 & -0.014 & 112.01 & 0.000 \\
\hline$* * *||$. & I. I & 17 & -0.327 & 0.022 & 127.71 & 0.000 \\
\hline$* * * 1.1$ & I*. । & 18 & -0.245 & 0.088 & 140.93 & 0.000 \\
\hline$* 1.1$ & $.1 * .1$ & 19 & -0.133 & 0.112 & 148.66 & 0.000 \\
\hline
\end{tabular}

Figure 3. Correlogram of $L_{t}(\operatorname{lag}=20)$.

It is clear from the ADF test (Table A4) that both the series (LIPs and LIRI) have unit root at their level values at 10 per cent, 5 per cent and 1 per cent significance level. That is, the series are non-stationary. The same properties of both series are confirmed by the PP test, which are shown in Table A5.

After the first differencing, the hypothesis of unit root is rejected in both series (see ADF test in Table A4 and A5). That is, both the series become stationary after first differencing. Therefore, they are integrated of order one, that is, I(1). These findings are also confirmed by the PP test except in case of L. But the correlogram, which shows Autocorrelation Functions (ACF) and Partial Autocorrelation Function (PACF) at different lags (Figures 3-6), confirms our findings.

\section{Co-integration}

Co-integration tests are conducted to ascertain any long-run equilibrium relationship between these two series. The basic purpose of the co-integration test is to determine 


\begin{tabular}{|c|c|c|c|c|c|c|}
\hline Autocorrelation & Partial Correlation & & $\mathrm{AC}$ & PAC & Q-Stat & Prob \\
\hline$|* * * * * * *|$ & $|* * * * * * *|$ & 1 & 0.878 & 0.878 & 17.851 & 0.000 \\
\hline$|* * * * * *|$ & ** . I & 2 & 0.734 & -0.160 & 31.028 & 0.000 \\
\hline$|* * * * *|$ & .1 .1 & 3 & 0.603 & -0.020 & 40.436 & 0.000 \\
\hline . $|* * * *|$ &.$* 1.1$ & 4 & 0.465 & -0.120 & 46.389 & 0.000 \\
\hline . I**. I &.$* 1.1$ & 5 & 0.317 & -0.134 & 49.336 & 0.000 \\
\hline $.1 * .1$ & $* 1.1$ & 6 & 0.169 & -0.108 & 50.231 & 0.000 \\
\hline .1 .1 & $* 1.1$ & 7 & 0.019 & -0.140 & 50.243 & 0.000 \\
\hline * *1. I & ***1. I & 8 & -0.146 & -0.215 & 51.023 & 0.000 \\
\hline.$* * 1.1$ &.$* 1.1$ & 9 & -0.287 & -0.067 & 54.309 & 0.000 \\
\hline$* * * 1.1$ & .1 .1 & 10 & -0.371 & 0.061 & 60.354 & 0.000 \\
\hline$* * * \mid .1$ & .1 .1 & 11 & -0.428 & -0.035 & 69.292 & 0.000 \\
\hline$* * * \mid .1$ & $.1 * .1$ & 12 & -0.439 & 0.104 & 79.911 & 0.000 \\
\hline$* * * \mid .1$ & .1 .1 & 13 & -0.423 & 0.015 & 91.140 & 0.000 \\
\hline$* * * 1.1$ & .1 .1 & 14 & -0.396 & -0.036 & 102.63 & 0.000 \\
\hline$* * * 1.1$ & .1 .1 & 15 & -0.358 & -0.025 & 113.90 & 0.000 \\
\hline.$* * 1.1$ & ${ }^{* 1} .1$ & 16 & -0.309 & -0.064 & 124.44 & 0.000 \\
\hline **1. I & $* 1.1$ & 17 & -0.252 & -0.071 & 133.77 & 0.000 \\
\hline .*1. I & .1 .1 & 18 & -0.183 & 0.002 & 141.13 & 0.000 \\
\hline * *1. I & $.1 * .1$ & 19 & -0.094 & 0.072 & 145.01 & 0.000 \\
\hline
\end{tabular}

Figure 4. Correlogram of $R_{t}(\mathrm{lag}=20)$.

\begin{tabular}{|c|c|c|c|c|c|c|}
\hline Autocorrelation & Partial Correlation & & $\mathrm{AC}$ & PAC & Q-Stat & Prob \\
\hline.$|* * . \quad|$ & . I**. | & 1 & 0.205 & 0.205 & 0.9314 & 0.335 \\
\hline .***| . I & .***| . I & 2 & -0.350 & -0.409 & 3.8033 & 0.149 \\
\hline .*1. I & .1 .1 & 3 & -0.185 & -0.000 & 4.6571 & 0.199 \\
\hline .*1. 1 & **1. I & 4 & -0.153 & -0.304 & 5.2810 & 0.260 \\
\hline . I**. I & . $|* * * \quad|$ & 5 & 0.238 & 0.382 & 6.8982 & 0.228 \\
\hline . $1 * * .1$ & .*1. I & 6 & 0.296 & -0.092 & 9.5825 & 0.143 \\
\hline * *1. I & .1 .1 & 7 & -0.143 & -0.001 & 10.262 & 0.174 \\
\hline .**1. I & . $* 1.1$ & 8 & -0.219 & -0.128 & 12.000 & 0.151 \\
\hline .*1. 1 & .1 .1 & 9 & -0.091 & 0.028 & 12.334 & 0.195 \\
\hline .1 .1 & * * .1 & 10 & -0.014 & -0.128 & 12.342 & 0.263 \\
\hline$* * 1$ & $. * * * \mid .1$ & 11 & -0.078 & -0.322 & 12.643 & 0.317 \\
\hline .1 .1 & .1 .1 & 12 & -0.054 & 0.039 & 12.808 & 0.383 \\
\hline .1 .1 & .*1. 1 & 13 & 0.026 & -0.095 & 12.854 & 0.459 \\
\hline .1 .1 & .1 .1 & 14 & -0.004 & 0.032 & 12.855 & 0.538 \\
\hline .1 .1 & . $* 1.1$ & 15 & 0.008 & -0.135 & 12.862 & 0.613 \\
\hline .1 .1 & . I*. I & 16 & 0.019 & 0.147 & 12.909 & 0.679 \\
\hline .1 .1 & .1 .1 & 17 & -0.011 & 0.007 & 12.935 & 0.741 \\
\hline .1 .1 & . *1. 1 & 18 & 0.009 & -0.064 & 12.968 & 0.793 \\
\hline
\end{tabular}

Figure 5. Correlogram of $\Delta L_{t}(\mathrm{lag}=20)$.

whether or not a group of non-stationary variables are co-integrated. Engle and Granger $^{31}$ point out that the two non-stationary variables can be used in regression if the linear combination of the two non-stationary variables is stationary. In such cases, the variables are said to be co-integrated. For two series to be co-integrated, both need to be integrated in the same order. Since the two variables in our study are 


\begin{tabular}{|c|c|c|c|c|c|c|}
\hline Autocorrelation & Partial Correlation & & $\mathrm{AC}$ & PAC & Q-Stat & Prob \\
\hline |**. | & . $1 * *$. I & 1 & 0.296 & 0.296 & 1.9396 & 0.164 \\
\hline$* * 1$ & .**1. 1 & 2 & -0.159 & -0.270 & 2.5307 & 0.282 \\
\hline .1 .1 & $.1 * .1$ & 3 & 0.010 & 0.176 & 2.5331 & 0.469 \\
\hline .1 .1 & .*1. 1 & 4 & 0.024 & -0.104 & 2.5486 & 0.636 \\
\hline$* * * 1.1$ & .**1. 1 & 5 & -0.240 & -0.223 & 4.1883 & 0.523 \\
\hline$* 1.1$ & $.1 * .1$ & 6 & -0.096 & 0.098 & 4.4734 & 0.613 \\
\hline . $1 * .1$ & .1 .1 & 7 & 0.088 & -0.028 & 4.7300 & 0.693 \\
\hline$* * 1$ & .**1. I & 8 & -0.138 & -0.198 & 5.4221 & 0.712 \\
\hline$* * * 1.1$ & .1 .1 & 9 & -0.194 & -0.024 & 6.9196 & 0.645 \\
\hline$* * 1$ & .**1. I & 10 & -0.168 & -0.293 & 8.1780 & 0.611 \\
\hline .1 .1 & . I**. I & 11 & 0.046 & 0.213 & 8.2829 & 0.688 \\
\hline .1 .1 & * *1. I & 12 & 0.050 & -0.104 & 8.4267 & 0.751 \\
\hline .1 .1 & .1 .1 & 13 & 0.010 & -0.033 & 8.4339 & 0.814 \\
\hline .1 .1 & .1 .1 & 14 & 0.016 & -0.004 & 8.4550 & 0.864 \\
\hline .1 .1 & $* 1.1$ & 15 & 0.011 & -0.141 & 8.4676 & 0.904 \\
\hline .1 .1 & .1 .1 & 16 & -0.037 & 0.025 & 8.6491 & 0.927 \\
\hline .1 .1 & .1 .1 & 17 & -0.038 & -0.023 & 8.9340 & 0.942 \\
\hline .1 .1 & $* * 1$ & 18 & 0.018 & -0.158 & 9.0692 & 0.958 \\
\hline
\end{tabular}

Figure 6. Correlogram of $\Delta R_{t}(\mathrm{lag}=20)$.

non-stationary and integrated of order $I(1)$, we have used the Engle-Granger cointegration test for the co-integration study. In order to test the co-integration of the series $L_{t}$ and $R_{t}$, we have estimated the following two equations [Eqs. (3) and (4)] and the residual series $U_{t}$ and $V_{t}$ of each estimated equation.

$$
\begin{aligned}
& L_{t}=\alpha+\beta R_{t}+U_{t} \\
& R_{t}=\gamma+\delta L_{t}+V_{t}
\end{aligned}
$$

The results of the estimated equations are as follows:

$$
\begin{aligned}
& L_{t}=8.7183+0.0793 R_{t} \\
& \text { S.E. (0.092) (0.003) } \\
& t \quad(94.467) \quad(20.804) \\
& R_{t}=-104.7880+12.1052 L_{t} \\
& \text { S.E. (5.982) (0.581) } \\
& \begin{array}{lll}
t \quad(-17.517) \quad(20.804)
\end{array}
\end{aligned}
$$

After we obtain the residuals, we plot them graphically (Figure 7) to determine whether or not they contain any trend and then we examined the same with the help of ADF test (Table 4) and PP test (Table 5) to check the unit root property.

The ADF test and the PP test on the residual series indicate that both the series are stationary at the 5 per cent and 10 per cent level. Therefore, both the LIPs and the life insurance reforms are co-integrated in the long run. The correlogram of the residual 


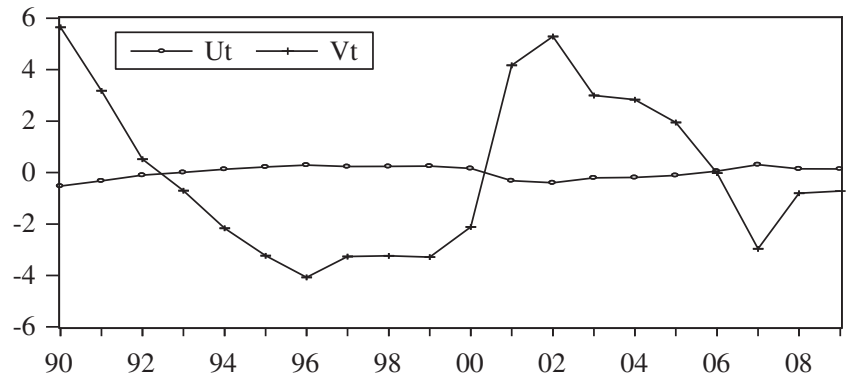

Figure 7. Graphical representation of residual series $U_{t}$ and $R_{t}$.

Table 4 ADF unit root test for lag length: 1 (automatic based on modified AIC, maximum lag=4)

\begin{tabular}{|c|c|c|c|c|c|c|}
\hline \multirow[t]{2}{*}{ Variables } & \multirow[t]{2}{*}{ Null hypothesis } & \multirow[t]{2}{*}{ ADF test stat. } & \multirow[t]{2}{*}{ Prob* $^{*}$} & \multicolumn{3}{|c|}{ Critical values } \\
\hline & & & & $1 \%$ & $5 \%$ & $10 \%$ \\
\hline$U_{t}$ & $U_{t}$ has a unit root (intercept) & -2.5519 & 0.014 & -2.6997 & -1.9614 & -1.6066 \\
\hline$V_{t}$ & $V_{t}$ has a unit root (intercept) & -2.2093 & 0.029 & -2.6923 & -1.9601 & -1.6070 \\
\hline
\end{tabular}

*MacKinnon (2000) one-sided $P$-values.

Table 5 Philips-Perron unit root test for bandwidth: 2 (Newey-West using Bartlett Kernel)

\begin{tabular}{llccccr}
\hline Variables & Null hypothesis & ADF test stat. & \multirow{2}{*}{ Prob $^{*}$} & & \multicolumn{2}{c}{ Critical values $^{2}$} \\
\cline { 5 - 7 } & & & & $1 \%$ & $5 \%$ & $10 \%$ \\
\hline$U_{t}$ & $U_{t}$ has a unit root (intercept) & -2.4581 & 0.0127 & -2.6923 & -1.9601 & -1.6070 \\
$V_{t}$ & $V_{t}$ has a unit root (intercept) & -2.3033 & 0.0241 & -2.6923 & -1.9601 & -1.6070 \\
\hline
\end{tabular}

*MacKinnon (2000) one-sided $P$-values.

(Figures 8 and 9) series also confirms that they are stationary, that is, $I(0)$. Now we can say that there is a stable long-run relationship between insurance reform and development in the life insurance sector.

\section{Vector error correction model (VECM)}

In this model, both the series become stationary after first differencing. But differencing may result in loss of information in the long-run relationship among the variables. Even if there exists a long-run equilibrium relationship between the two series, there may be disequilibrium in the short run. Engle and Granger identify that the co-integrated variables must have an Error Correction Model (ECM) representation and a VAR model can be reformulated by the means of all level variables. The Vector Error Correction specification restricts the long-run behaviour of the endogenous variables to converge to their co-integrated relationships while 


\begin{tabular}{|c|c|c|c|c|c|c|}
\hline Autocorrelation & Partial Correlation & & $\mathrm{AC}$ & PAC & Q-Stat & Prob \\
\hline . $|* * * * *|$ &.$|* * * * *|$ & 1 & 0.660 & 0.660 & 10.083 & 0.001 \\
\hline.$|* *|$. & $* * * 1.1$ & 2 & 0.262 & -0.306 & 11.767 & 0.003 \\
\hline .1 .1 & .*1. 1 & 3 & -0.043 & -0.132 & 11.816 & 0.008 \\
\hline.$* * 1.1$ & $* * * 1$ & 4 & -0.309 & -0.270 & 14.441 & 0.006 \\
\hline$* * * * \mid, 1$ & $* * *||$. & 5 & -0.538 & -0.325 & 22.938 & 0.000 \\
\hline$* * * *||$, &.$* 1.1$ & 6 & -0.581 & -0.127 & 33.539 & 0.000 \\
\hline$* * * \mid$. I & .1 .1 & 7 & -0.424 & -0.030 & 39.635 & 0.000 \\
\hline$* * * 1$ & $* * 1.1$ & 8 & -0.270 & -0.228 & 42.316 & 0.000 \\
\hline$* * 1.1$ & .*1. I & 9 & -0.087 & -0.087 & 42.622 & 0.000 \\
\hline . ${ }^{*}$. & .1 .1 & 10 & 0.135 & -0.043 & 43.425 & 0.000 \\
\hline.$|* * * \quad|$ & $.1 * .1$ & 11 & 0.384 & 0.151 & 50.626 & 0.000 \\
\hline $.1 * * * \quad \mid$ & $* * 1.1$ & 12 & 0.361 & -0.289 & 57.781 & 0.000 \\
\hline . I**. I & .*1. 1 & 13 & 0.239 & -0.084 & 61.369 & 0.000 \\
\hline $.1 * .1$ & .1 .1 & 14 & 0.146 & -0.044 & 62.928 & 0.000 \\
\hline .1 .1 &.$* 1.1$ & 15 & 0.022 & -0.083 & 62.971 & 0.000 \\
\hline$* * 1.1$ & .1 .1 & 16 & -0.116 & -0.024 & 64.442 & 0.000 \\
\hline * * . I & .1 .1 & 17 & -0.180 & -0.012 & 69.204 & 0.000 \\
\hline **1. 1 & $.1 * .1$ & 18 & -0.099 & 0.081 & 71.345 & 0.000 \\
\hline 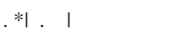 & .1 .1 & 19 & -0.061 & -0.029 & 72.957 & 0.000 \\
\hline
\end{tabular}

Figure 8. Correlogram of $U_{t}(\operatorname{lag}=20)$.

\begin{tabular}{|c|c|c|c|c|c|c|}
\hline Autocorrelation & Partial Correlation & & $\mathrm{AC}$ & PAC & Q-Stat & Prob \\
\hline.$|* * * * *|$ &.$|* * * * *|$ & 1 & 0.687 & 0.687 & 10.921 & 0.001 \\
\hline $.1 * * . \quad \mid$ & ***1. I & 2 & 0.303 & -0.319 & 13.166 & 0.001 \\
\hline .1 .1 & $* 1.1$ & 3 & 0.016 & -0.083 & 13.173 & 0.004 \\
\hline ***1. I & $* * \mid .1$ & 4 & -0.252 & -0.288 & 14.922 & 0.005 \\
\hline$* * * * \mid 1$ & $* * \mid .1$ & 5 & -0.504 & -0.317 & 22.372 & 0.000 \\
\hline$* * * * 1.1$ &.$* 1.1$ & 6 & -0.573 & -0.083 & 32.706 & 0.000 \\
\hline$* * * \mid .1$ & .1 .1 & 7 & -0.447 & -0.005 & 39.471 & 0.000 \\
\hline$* * * 1.1$ & $* * 1.1$ & 8 & -0.338 & -0.256 & 43.669 & 0.000 \\
\hline ***1. I &.$* 1.1$ & 9 & -0.196 & -0.077 & 45.205 & 0.000 \\
\hline .1 .1 & .1 .1 & 10 & 0.023 & -0.034 & 45.227 & 0.000 \\
\hline $.1 * * . \quad 1$ & $.1 * .1$ & 11 & 0.282 & 0.139 & 49.124 & 0.000 \\
\hline $.1 * * . \quad 1$ & $* * * 1.1$ & 12 & 0.293 & -0.331 & 53.838 & 0.000 \\
\hline $.1 * * . \quad 1$ & $* 1.1$ & 13 & 0.208 & -0.110 & 56.558 & 0.000 \\
\hline $.1 * .1$ & .*1. I & 14 & 0.152 & -0.122 & 58.243 & 0.000 \\
\hline .1 .1 & $* 1.1$ & 15 & 0.062 & -0.102 & 58.578 & 0.000 \\
\hline .1 .1 & .1 .1 & 16 & -0.051 & -0.048 & 58.859 & 0.000 \\
\hline.$* 1.1$ & $* 1.1$ & 17 & -0.105 & -0.071 & 60.482 & 0.000 \\
\hline .1 .1 & .1 .1 & 18 & -0.036 & -0.005 & 60.775 & 0.000 \\
\hline .1 .1 & *1. I & 19 & -0.022 & -0.099 & 60.984 & 0.000 \\
\hline
\end{tabular}

Figure 9. Correlogram of $V_{t}(\operatorname{lag}=20)$.

allowing a wide range of short-run dynamics; hence, one can treat the error terms (ET) as the "equilibrium error". Through the co-integration term, the deviation from the long-run equilibrium is corrected gradually in the course of a series of short-run adjustments. Therefore, VECM gives us important information about the short-run 
relationships between these two co-integrated variables. The general form of this modified equation by employing variables of our study is presented below:

$$
\begin{gathered}
\Delta L_{t}=\alpha_{1}+\beta_{1} E T_{1 t-i}+\sum_{i=1}^{n} \delta \Delta L_{t-i}+\sum_{i=1}^{n} \gamma \Delta R_{t-i}+\varepsilon_{t} \\
\Delta R_{t}=\alpha_{2}+\beta_{2} E T_{2 t-i}+\sum_{i=1}^{n} \theta \Delta R_{t-i}+\sum_{i=1}^{n} \lambda \Delta L_{t-i}+\omega_{t}
\end{gathered}
$$

where, $\varepsilon_{t}$ and $\omega_{t}$ are white noise error terms, and ET is equal to $E T=\left[\Delta L_{t-i}-\left(\Delta R_{t-i}\right)\right]$, which is the long-run effect and lagged independent variables are short-run effect. That is, changes in the dependent variables are affected by the $E T, \Delta L_{t-i}$ and $\Delta R_{t-i}$.

Before estimating the VECM with the co-integrated vectors, it is necessary to identify and select the optimal lag length of initial VAR. Therefore, different information criteria were computed for different time lags. On the basis of the evidence provided by the Akaike's Information Criterion, we have selected optimal lag 4 in our study. The results of the VECM coefficient estimations are summarised in Table A6 (Appendix).

\section{Findings from VECM}

From VECM, the estimated equation functions have the following forms:

$$
\begin{aligned}
\Delta L_{t}= & -0.5827\left(L_{t-1}-0.7586 R_{t-1}-8.8469\right)+0.2860 \Delta L_{t-1} \\
& +0.7991 \Delta L_{t-2}-2.0264 \Delta L_{t-3}-2.4603 \Delta L_{t-4}-0.0220 \Delta R_{t-1} \\
& -0.0663 \Delta R_{t-2}+0.0070 \Delta R_{t-3}+0.0487 \Delta R_{t-4}+0.9906 \\
\Delta R_{t}= & 3.400\left(L_{t-1}-0.7586 R_{t-1}-8.8469\right)+0.9762 \Delta L_{t-1} \\
+ & 5.6695 \Delta L_{t-2}-36.6698 \Delta L_{t-3}-38.2314 \Delta L_{t-4}+0.2776 \Delta R_{t-1} \\
- & 0.6835 \Delta R_{t-2}+0.5899 \Delta R_{t-3}+1.0555 \Delta R_{t-4}+14.2357
\end{aligned}
$$

From the above results, we can observe that the co-integrating vector coefficients in the long run in both the equations are significant at the 5 per cent level. This indicates that the system is in the state of short-term dynamics. In the short run, in case of Eq. (7), the lagged values of first, second and fourth year of $R_{t}$ variable have significant influence on $L_{t}$ (LIP volume) along with the lagged values of all four consecutive years of $L_{t}$. On the other hand, in Eq. (8), the dependant variable $R_{t}$ is not significantly dependent on any lagged values of $L_{t}$ and $R_{t}$.

\section{The causal relationship}

A long-run relationship implies that there must be at least one causal relationship existing among the variables. Therefore, the next step is to find out whether reforms in the life insurance sector promote the development of life insurance business in 
Table 6 VEC granger causality

\begin{tabular}{lccc}
\hline Excluded & $C h i^{2}$ & $d f$ & Prob. \\
\hline (a) Dependent variable: $\Delta L$ & & & \\
$\Delta R$ & $70.9737^{*}$ & 4 & 0.0000 \\
All & 70.9737 & 4 & 0.0000 \\
& & & \\
(b) Dependent variable: $\Delta R$ & 4.1168 & 4 & 0.3904 \\
$\Delta L$ & 4.1168 & 4 & 0.3904 \\
All & & & \\
\hline
\end{tabular}

* Significant at 1 per cent level.

India or the overall development in the life insurance sector helps to increase the reform process in the life insurance sector. Since the series in our study are $I(1)$ and co-integrated, the proper statistical inference can be obtained by analysing the causality relationship on the basis of ECM as the simple F statistic in the traditional Granger causality test does not have a standard distribution. The result of the VEC Granger causality test (in Table 6(a) and (b)) shows that the relationship between the two variables (LIP and LIRI) in India is unidirectional, which means life insurance reforms in India improve the total development in the insurance sector and the reverse is not true.

\section{Conclusion}

The effect of the insurance sector reforms on the development of the life insurance sector is very important and highly debatable in India. In an attempt to shed light on this issue, the present study investigates the relationship between life insurance sector reforms and the overall development of life insurance business in recent years in India by applying the VAR-VECM econometric methodology. The ADF test and the PP test statistics were used to test the unit root properties of the variables. It is clear from the above empirical study that the life insurance sector reforms improved the overall development of life insurance in recent years in India. The VEC Granger causality test shows that the life insurance sector reforms caused the overall life insurance development in India.

In summary, the results of this study support the supposition that reforms in the insurance sector improve the overall development of this sector and if we could improve upon the reform process in the life insurance sector, we would be able to see more development in this segment. It would be interesting to know further whether the development of the insurance sector has any impact on economic development in the post-reform period in India. If we could improve upon the reform process in the life insurance sector, we would be able to see more development in this segment and ultimately an improvement in the economy. Therefore, policymakers should improve upon the reforms/reform process in the life insurance sector for the development of the life insurance sector itself and for the development of the Indian economy due to the important role played by the insurance industry. 


\section{References}

Annual Report of IRDA, Financial Year (1999/2000 to 2000/2001) Available at www.irda.org.in.

Annual Report of IRDA (2000/2001 to 2009/2010) IRDA, Hyderabad, India; http://www.irda.gov.in/ ADMINCMS/cms/frmGeneral_NoYearList.aspx?DF=AR\&mid=11.1.

Arena, M. (2008) 'Does insurance market activity promote economic growth? A cross country study of industrialized and developing countries', Journal of Risk and Insurance 75(4): 921-946.

Beck, T. and Webb, I. (October, 2002) Economic, demographic and institutional determinants of life insurance consumption across countries, working paper, World Bank and International Insurance Foundation.

Beck, T., Levine, R. and Loayza, N. (2000) 'Finance and the sources of growth', Journal of Financial Economics 58(1-2): 261-300.

Browne, M.J. and Kim, K. (1993) 'An international analysis of life insurance demand', Journal of Risk and Insurance 60(4): 616-634.

Browne, M.J., Chung, J. and Frees, E.W. (2000) 'International property-liability insurance consumption', Journal of Risk and Insurance 67(1): 73-90.

Catalan, M., Impavido, G. and Musalem, A.R. (August, 2000) 'Contractual savings or stock markets: Which leads?', Financial Sector Development Department, the World Bank.

Dickey, D.A. and Fuller, W.A. (1979) 'Distribution of the estimators for autoregressive time series with a unit root', Journal of the American Statistical Association 74: 427-431.

Engle, R. and Granger, C.W.J. (1987) 'Co-integration and error correction: Representation, estimation and testing', Econometrica 55: 251-276.

Esho, N., Kirievsky, A., Ward, D. and Zurbruegg, R. (2004) 'Law and the determinants of property casualty insurance', Journal of Risk and Insurance 71(2): 265-283.

Han, L., Li, D., Moshirian, F. and Tian, Y. (2010) 'Insurance development and economic growth', The Geneva Papers on Risk and Insurance - Issues and Practice 35(2): 183-199.

Hwang, T. and Greenford, B. (2005) 'A cross-section analysis of the determinants of life insurance consumption in mainland China, Hong Kong, and Taiwan', Risk Management and Insurance Review 8(1): 103-125.

Hwang, T. and Gao, S. (2003) 'The determinants of demand for life insurance in an emerging economy The case of China', Managerial Finance 29(5/6): 82-96.

King, R.G. and Levine, R. (1993a) 'Finance, entrepreneurship and growth: Theory and evidence', Journal of Monetary Economics 32: 513-542.

King, R.G. and Levine, R. (1993b) 'Finance and growth: Schumpeter might be right', Quarterly Journal of Economics 108(3): 717-737.

Levine, R. and Zervos, S. (1998) 'Stock markets, banks and economic growth', American Economic Review 88(3): 537-558.

Levine, R. (1997) 'Financial development and economic growth: Views and agenda', Journal of Economic Literature 35(2): 688-726.

Levine, R., Loayza, N. and Beck, T. (2000) 'Financial intermediation and growth: Causality and causes', Journal of Monetary Economics 46(1): 31-77.

Lim, C.C. and Haberman, S. (2004) Modeling Life Insurance Demand from a Macroeconomic Perspective: The Malaysian Case, Paper presented at The 8th International Congress on Insurance: Mathematics \& Economics, Rome, http://www.ime2004rome.com/fullpapers/Chee\%20PAPE.pdf.

MacKinnon, J.G. (2000) 'Numerical distribution functions for unit root and cointegration tests', Journal of Applied Econometrics 11: 601-618.

Mitra, D. and Ghosh, A. (2009) 'Rural life insurance in post reform era in India: Growth and opportunities', International Journal of Rural Development and Management Studies 3(2): 241-257.

Mitra, D. and Ghosh, A. (2010) 'Determinants of life insurance demand in India in the post economic reform era (1991-2008)', International Journal of Business Management, Economics and Information Technology 2(1): 19-36.

Outreville, J.F. (1990) 'The economic significance of insurance markets in developing countries', Journal of Risk and Insurance 18(3): 487-498.

Outreville, J.F. (1996) 'Life insurance markets in developing countries', Journal of Risk and Insurance 63(2): 263-278.

Phillips, P.C.B. and Perron, P. (1987) 'Testing for a unit root in time series regression', Biometrica 75(2): $335-346$ 
Rajagopalan, R. (2004) Valuing Term Insurance Products in Indian Market, Paper Presented at the Fifth Global Conference of Actuaries, January, India.

Ranade, A. and Ahuja, R. (1999) 'Life insurance in India: Emerging issues', Economic and Political Weekly, January (16-23), pp. 203-212.

Rao, D.T. (2000) 'Privatisation and foreign participation in (Life) insurance sector', Economic and Political Weekly, 25 March, pp. 1107-1120.

Sinha, R. and Chatterjee, B. (2009) Are Indian life insurance companies cost efficient?, Working paper presented at 11 th annual conference on Money and Finance in the India economy.

Sinha, T. (2004) The Indian insurance industry: Challenges and prospects, Swiss Re Visiting Professor, Institute of Insurance and Risk Management, Hyderabad, India, p. 24.

Tadas, G.A. (1994) 'Some issues in liberalising India's financial sector', in Trade in Services: The Uruguay Round and After, New Delhi, India: Indian Institute of Foreign Trade.

Tone, K. and Sahoo, B.K. (2005) 'Evaluating cost efficiency and return to scale in the Life Insurance Corporation of India using data envelopment analysis', Socio-economic Planning Science 39(4): 261-285.

UNCTAD (1993) 'Insurance in developing countries: Privatisation and insurances enterprises and liberalisation of insurance markets', 19 January, http://books.google.co.in/books/about/Insurance_in_ developing_countries.html?id=aptAbwAACAAJ\&redir_esc $=y$.

Vadlamannati, K. (2008) 'Do insurance sector growth and reforms affect economic development? Empirical evidence from India', Margin: The Journal of Applied Economic Research 2: 43-86.

Ward, D. and Zurbruegg, R. (2002) 'Law, politics and life insurance consumption in Asia', The Geneva Papers on Risk and Insurance-Issues and Practice 27: 395-412.

Zhang, C. and Zhu, N. (2005) 'Determinants of the development of insurance in China under the globalization', www.cerdi.org/colloque/CHINE2005/papier/Zhang_31.pd.

\section{Appendix}

Table A1 Chronology of reforms in the life insurance sector

1993 Setting up of The Malhotra Committee
1994 Recommendations of the Committee released
1995 Setting up of the Mukherjee Committee
1996 Setting up of (interim) Insurance Regulatory Authority (IRA).
1997 Mukherjee Committee report submitted but not made public.
A Standing Committee on reforms created.
Govt. gives greater autonomy to LICI
1998 Cabinet decides to allow 40 per cent foreign equity in private insurance companies, 26 per cent to
foreign companies and 14 per cent to NRIs, OCBs and FIIs.
Setting up of the TAC
The Standing Committee headed by Mr. Murli Deora decides that foreign equity in private
insurance companies should be limited to 26 per cent. The IRA Act was renamed as The Insurance
Regulatory and Development Authority (IRDA) Act.
Cabinet clears the IRDA Act
The President gives assent to The IRDA Act.

Source: IRDA annual reports.

$\mathrm{NRI}=$ non resident Indians, $\mathrm{OCB}=$ overseas corporate bodies, $\mathrm{FII}=$ foreign institutional investors,

$\mathrm{TAC}=$ tariff advisory committee. 
The Geneva Papers on Risk and Insurance-Issues and Practice

110

Table A2 Calculation of life insurance reforms index (LIRI) in India

\begin{tabular}{llll}
\hline Years & $\begin{array}{c}\text { FDI } \\
\text { (total } \begin{array}{c}\text { nof comp.) } \\
\text { of }\end{array}\end{array}$ & Regulatory reforms & LIRI index \\
\hline $1989-1990$ & 01 & 0 & 1.00 \\
$1990-1991$ & 01 & 0 & 1.00 \\
$1991-1992$ & 01 & 0 & 1.00 \\
$1992-1993$ & 01 & 1 & 2.00 \\
$1993-1994$ & 01 & 2 & 3.00 \\
$1994-1995$ & 01 & 3 & 4.00 \\
$1995-1996$ & 01 & 4 & 5.00 \\
$1996-1997$ & 01 & 7 & 8.00 \\
$1997-1998$ & 01 & 9 & 10.00 \\
$1998-1999$ & 01 & 11.5 & 12.00 \\
$1999-2000$ & 01 & 15 & 15.50 \\
$2000-2001$ & 11 & 17.5 & 26.00 \\
$2001-2002$ & 14 & 17.75 & 31.50 \\
$2002-2003$ & 13 & 18.50 & 30.50 \\
$2003-2004$ & 14 & 19.25 & 32.50 \\
$2004-2005$ & 15 & 19.25 & 34.25 \\
$2005-2006$ & 16 & 20 & 35.25 \\
$2006-2007$ & 17 & 21.25 & 37.00 \\
$2007-2008$ & 21 & 21.50 & 42.25 \\
$2008-2009$ & 22 & & 43.50 \\
\hline
\end{tabular}

Table A3 ADF unit root test. Lag length: (automatic based on modified AIC, maximum lag=4)

\begin{tabular}{llrrrrrr}
\hline Variables & Null hypothesis & ADF test & Prob & DW stat & & & \multicolumn{2}{c}{ Critical values } \\
\cline { 4 - 8 } & & & & & & & \\
& & & & & $5 \%$ & $10 \%$ \\
\hline LIP & LIP has a unit root (intercept) & 3.905 & 0.999 & 1.746 & -2.7282 & -1.9662 & -1.6050 \\
LIRI & LIRI has a unit root (intercept \& trend) & 2.5694 & 0.295 & 1.866 & -4.5715 & -3.6908 & -3.2869 \\
WPI & WPI has a unit root (intercept) & -1.5836 & 0.998 & 1.541 & -3.8315 & -3.0299 & -2.6551 \\
GDPI & GDPI has a unit root (none) & 3.1290 & 0.998 & 1.950 & -3.8315 & -3.0299 & -2.6551 \\
GDS & GDS has a unit root (intercept) & 1.3460 & 0.997 & 2.078 & -3.8315 & -3.0299 & -2.6551
\end{tabular}

${ }^{a}$ MacKinnon (2000) on-sided $P$-values.

Table A4 ADF unit root test for lag length: 1 (automatic based on modified AIC, maximum lag =4)

\begin{tabular}{|c|c|c|c|c|c|c|c|}
\hline \multirow[t]{2}{*}{ Variables } & \multirow[t]{2}{*}{ Null hypothesis } & \multirow{2}{*}{$\begin{array}{c}\text { ADF test } \\
\text { stat. }\end{array}$} & \multirow[t]{2}{*}{$\operatorname{Prob}^{\mathrm{a}}$} & \multirow[t]{2}{*}{ DW stat } & \multicolumn{3}{|c|}{ Critical values } \\
\hline & & & & & $1 \%$ & $5 \%$ & $10 \%$ \\
\hline$L$ & $L$ has a unit root (intercept $\&$ trend) & 3.905 & 0.999 & 1.746 & -2.7282 & -1.9662 & -1.6050 \\
\hline$\Delta L$ & $L$ has a unit root (intercept) & -3.6727 & 0.015 & 1.999 & -3.8867 & -3.0521 & -2.6665 \\
\hline$R$ & $R$ has a unit root (intercept $\&$ trend) & 2.5694 & 0.295 & 1.866 & -4.5715 & -3.6908 & -3.2869 \\
\hline$\Delta R$ & $R$ has a unit root (intercept) & -1.9787 & 0.048 & 1.877 & -2.6997 & -1.9614 & -1.6066 \\
\hline
\end{tabular}

${ }^{a}$ MacKinnon (2000) one-sided $P$-values. 
Table A5 Philips-Perron unit root test for bandwidth: 2 (Newey-West using Bartlett Kernel)

\begin{tabular}{llllllll}
\hline Variables & Null hypothesis & $\begin{array}{c}\text { ADF test } \\
\text { stat. }\end{array}$ & Prob $^{\mathrm{a}}$ & DW stat & & \multicolumn{2}{c}{ Critical values } \\
\cline { 4 - 8 } & & & & & $1 \%$ & $5 \%$ & $10 \%$ \\
\hline$L$ & $L$ has a unit root (intercept \& trend) & -2.4859 & 0.997 & 1.540 & -3.8315 & -3.0299 & -2.6551 \\
$\Delta L$ & $L$ has a unit root (intercept) & -2.5956 & 0.112 & 1.889 & -3.8573 & -3.0403 & -2.6605 \\
$R$ & $R$ has a unit root (intercept \& trend) & -2.4859 & 0.9948 & 1.541 & -2.6923 & -1.9601 & -1.6070 \\
$\Delta R$ & $R$ has a unit root (intercept) & -1.9610 & 0.050 & 1.903 & -2.6997 & -1.9614 & -1.6066 \\
\hline
\end{tabular}

${ }^{a}$ MacKinnon (2000) one-sided $P$-values.

Table A6 Results of VECM coefficients estimation

\begin{tabular}{lrrr}
\hline Variables & Coefficients & t-statistics & Standard erro \\
\hline $\begin{array}{l}\text { Co-integrating vector coefficients } \\
L_{t-1}\end{array}$ & & \\
$R_{t-1}$ & 1.0000 & $-89.6275^{\mathrm{a}}$ & 0.0008 \\
$C$ & -0.0758 & &
\end{tabular}

\begin{tabular}{|c|c|c|c|c|}
\hline \multicolumn{5}{|c|}{ VECM coefficients } \\
\hline $\begin{array}{l}\text { Dependent } \\
\text { variable }\end{array}$ & $\begin{array}{l}\text { Explanatory } \\
\text { variable }\end{array}$ & Coefficients & $t$-statistics & $\begin{array}{c}\text { Standard } \\
\text { errors }\end{array}$ \\
\hline \multirow{10}{*}{ (a) $\Delta L_{t}$} & Constant & 0.9906 & $8.9127^{*}$ & 0.1110 \\
\hline & $E T_{1 \mathrm{t}-1}$ & -0.5827 & $-6.0044^{*}$ & 0.0975 \\
\hline & $\Delta L_{t-1}$ & 0.2860 & $1.7746^{* *}$ & 0.1619 \\
\hline & $\Delta L_{t-2}$ & 0.7991 & $3.4631^{*}$ & 0.2307 \\
\hline & $\Delta L_{t-3}$ & -2.0264 & $-6.7589 *$ & 0.2998 \\
\hline & $\Delta L_{t-4}$ & -2.4603 & $-5.2980^{*}$ & 0.4644 \\
\hline & $\Delta R_{t-1}$ & -0.0220 & $-3.8876^{*}$ & 0.0056 \\
\hline & $\Delta R_{t-2}$ & -0.0663 & $-7.6917 *$ & 0.0086 \\
\hline & $\Delta R_{t-3}$ & -0.0070 & 0.6878 & 0.0102 \\
\hline & $\Delta R_{t-4}$ & 0.0487 & $4.2805^{*}$ & 0.0113 \\
\hline \multirow[t]{10}{*}{ (b) $\Delta R_{t}$} & Constant & 14.2357 & 1.4160 & 10.0531 \\
\hline & $E T_{2 t-1}$ & 3.4001 & 0.3871 & 8.7819 \\
\hline & $\Delta L_{t-1}$ & -0.9762 & -0.0669 & 14.5861 \\
\hline & $\Delta L_{t-2}$ & 5.6695 & 0.2715 & 20.8822 \\
\hline & $\Delta L_{t-3}$ & -36.6698 & -1.3515 & 27.1317 \\
\hline & $\Delta L_{t-4}$ & -38.2314 & -0.9097 & 42.0240 \\
\hline & $\Delta R_{t-1}$ & 0.2776 & 0.5403 & 0.5139 \\
\hline & $\Delta R_{t-2}$ & -0.6835 & -0.8759 & 0.7803 \\
\hline & $\Delta R_{t-3}$ & 0.5899 & 0.6346 & 0.9295 \\
\hline & $\Delta R_{t-4}$ & 1.0555 & 1.0243 & 1.0304 \\
\hline
\end{tabular}

${ }^{a}$ Null hypothesis that estimated coefficient is equal to zero can be rejected at the 1 per cent level. Note: *,** indicates significant at the 1 per cent, 5 per cent and 10 per cent levels. 


\section{About the Author}

Amlan Ghosh is an Assistant Professor in Finance at School of Management and Commerce, Sikkim University, Sikkim, India. His keen interest lies in the fields of Insurance and Pension markets in India and Asia. He is also a reviewer of leading journals such as Asia Pacific Journal of Risk and Insurance, Singapore and Global Journal of Business, Management and Accounting (GJBMA). 